\title{
Faecal Contamination in Ground Water Resources of Urban Areas of Ujjain
}

\author{
${ }^{1}$ Vikas Parmar*, ${ }^{2}$ Madhubala Purohit
}

${ }^{1}$ Research student Department of Botany Government Madhav Science P.G.College, Ujjain, M.P., India

${ }^{2}$ Professor, Department of Botany Government Madhav Science P.G.College, Ujjain, M.P., India

\begin{abstract}
Ground water is one of the most important natural resource next to air being essential for life. Quality of ground water depends upon natural process, such as wet/dry condition, salts, many geogenic and anthropogenic activities. Among all contamination ground water is more susceptible to microbial contamination. According to WHO report about $80 \%$ of all diseases in human being are caused due to drinking water contaminated by bacteria of faecal origin. Various water born diseases are prevalent in Ujjain like typhoid, dysentery, jaundice, amebeosis, colitis etc. Purpose of the study was to assess the bacterial contamination of faecal origin in ground water resources of urban area of Ujjain. For this ground water samples (well, bore well and hand pump) were collected from 6 sub areas of Ujjain city. For the assessment of bacterial contamination of faecal origin H2S strip test of Manja,et.al.(1982) was used. Results clearly indicated that bore well water was found to be safe for drinking, domestic and other purposes.
\end{abstract}

Keywords: Anthropogenic, geogenic activities, bacterial contamination of faecal origin, H2S strip test, ground water and microbial contamination.

\section{Introduction:}

Ground water is an important natural resource present beneath the earth surface, which contained balanced concentration of salts (Yadav, et.al., 2012). Ground water constitutes the major source of drinking water in India (Pahuja, 2010 and wyrwoll, 2012).

$50 \%$ of urban water need is fulfilled by ground water resources of developing country (Meenakshi and Maheshwari, 2006; Shankar, et.al. 2011; Sowrabha and Narayana,2014). According to Department of drinking water supply. 60-70\% population of Ujjain depend upon ground water resources for drinking, domestic and other purposes (Neelam. Sharma and Madhu Purohit,2012).

On the basis of the survey we found that population of Ujjain is largely dependent upon ground water resources. They are not aware of ground water quality due to lack of awareness, uneducation and misconception amongst them that ground water is the purest form of drinking water free from any type of pollution. Therefore, it is necessary to assess the quality of ground water in different areas of Ujjain with special reference to bacterial contamination of faecal origin.

\section{Study area:}

Ujjain is located in the central part of Madhya Pradesh, India. It is an ancient city situated on the eastern bank of river Kshipra. Coordinates of Ujjain are $23^{\circ} 11^{\prime} \mathrm{N}$ and $75^{\circ} 46^{\prime} \mathrm{E}$ with an average elevation of $494 \mathrm{~m}$ (1620ft). Samples were collected from six areas of Ujjain city viz.- Madhav nagar, Dewas road, Indore road, Maxi road, Agar road and Mahakal road.

\section{Material and Methods:}

In total of 60 ground water samples were collected in June 2015 from wells, bore wells and hand pumps six major areas of Ujjain city and analyzed by $\mathrm{H}_{2} \mathrm{~S}$ strip test of Manja,et.al.,1982. Sampling was done early in the morning in $\mathrm{H}_{2} \mathrm{~S}$ bottle containing a $\mathrm{H}_{2} \mathrm{~S}$ strip (a ready made field kit) directly and bought to the laboratory of Govt. Madhav Science College, Ujjain samples were kept in the incubator at $37^{0} \mathrm{c}$. Change in 
colour of water sample was recorded $24 \mathrm{hrs}$ up to $72 \mathrm{hrs}$. The samples which became black after incubation showed the presence of bacteria of faecal origin.

\section{Results and Discussion:}

Results clearly showed that 18 out of 20 well samples (90\%) (Table1) showed the presence of bacteria of faecal origin by $\mathrm{H}_{2} \mathrm{~S}$ strip test. Amongst 18 samples 4 samples showed slight, 7 moderate, 3 high and 4 very high degree of contamination (Table-2). Onuigbo,et.al.(2017) studied the impact of bacterial pollution on hand - dug well water quality in Enugu,Nigeria. They collected water samples from ten hand-dug wells and found contamination in all the ten samples.

In bore well water samples contamination was reported in 8 samples. 2 samples showed slight, 2 moderate, I high and 1 sample showed very high degree of contamination. In water samples of hand pump contamination was reported in 9 samples. 6 samples showed slight, 1moderate and 2 samples showed high contamination.

Javed,et.al (2013) checked the bacteriological quality of three ground water resources (open well, tube well and hand pump) of ten localities of Peshawar rural areas of Pakistan. They found that bacterial count in tube well of four localities were as per WHO standards and fit for drinking purpose. Among hand pump water samples $92 \%$ of samples were found to be unfit for drinking purpose. Open well water samples of only two localities were found to be fit for human consumption.

\section{Conclusion:}

Results clearly showed that most of the bore well water samples were safe for drinking purpose. Only 3 out of 8 samples showed very high contamination. In many residential colonies of urban areas of Ujjain water resources were installed in the vicinity of the potential sources of faecal contamination like defective septic tanks, soak pits and drainage pipe lines. In addition, well maintained cement concrete platform around the ground water resource is not built resulting in polluted water to percolate down and contaminate the source.

\section{Recommendations:}

1. Maximum well samples were found to be unfit for drinking purpose. Therefore pretreatment of water should be done

2. Bore well water is comparatively safer for drinking purpose from the point of view of bacterial contamination.

3. Special care should be taken to construct leak proof septic tanks and soak pits in residential colonies.

4. Water samples of every ground water resource should be tested before using for drinking purpose.

5. General awareness amongst urban population regarding the ground water quality is necessary.

Table 1: Assessment of Faecal Contamination of Ground Water Resources in by $\mathrm{H}_{2} \mathrm{~S}$ Strip Test.

\begin{tabular}{|c|c|c|c|c|c|}
\hline S.No. & Area & Sub area & Well & Bore well & Hand pump \\
\hline \multirow[t]{3}{*}{1} & \multirow[t]{3}{*}{ Madhav Nagar Area } & Rajasva colony & +++ & ++ & + \\
\hline & & Freeganj & + & +++ & +++ \\
\hline & & Grand hotel & - & + & + \\
\hline \multirow[t]{4}{*}{2} & \multirow[t]{4}{*}{ Dewas Road Area } & Rishi nagar & ++ & + & + \\
\hline & & Mahananda nagar & ++ & ++ & - \\
\hline & & Aanand nagar & ++++ & ++++ & - \\
\hline & & Industrial area & ++ & - & +++ \\
\hline \multirow[t]{2}{*}{3} & \multirow[t]{2}{*}{ Indore Road Area } & Sindhi colony & ++ & - & - \\
\hline & & Sant nagar & ++ & ++++ & - \\
\hline \multirow[t]{2}{*}{4} & \multirow[t]{2}{*}{ Maxi Road Area } & Industrial area & + & - & + \\
\hline & & Anjusha colony & ++ & - & - \\
\hline
\end{tabular}




\begin{tabular}{|c|c|c|c|c|c|}
\hline & & Sethi nagar & + & - & - \\
\hline \multirow[t]{4}{*}{5} & \multirow[t]{4}{*}{ Agar Road Area } & Chamunda chauraha & ++++ & ++++ & ++ \\
\hline & & Mohan nagar & ++++ & - & - \\
\hline & & Indira nagar & ++ & - & + \\
\hline & & Industrial area & +++ & - & - \\
\hline \multirow[t]{4}{*}{6} & \multirow[t]{4}{*}{ Mahakal Road Area } & Budhwariya & - & - & - \\
\hline & & Gudari chauraha & ++++ & - & - \\
\hline & & Ganesh colony & + & - & + \\
\hline & & Jaisingh pura & +++ & - & - \\
\hline
\end{tabular}

Note: - (-) No, (+) slight, $(++)$ moderate, $(+++)$ high, $(++++)$ very high contamination.

Table 2: Degree of Bacterial contamination of faecal origin in ground water samples of Ujjain.

\begin{tabular}{|l|l|l|l|l|l|}
\hline S.No & \multirow{2}{*}{ Resources } & \multicolumn{2}{l|}{ Degree of contamination } \\
\cline { 4 - 7 } & & Slight & Moderate & High & Very high \\
\hline 1 & Well & 4 & 7 & 3 & 4 \\
\hline 2 & Bore well & 2 & 2 & 1 & 3 \\
\hline 3 & Hand pump & 6 & 1 & 2 & 0 \\
\hline Total & & 12 & 10 & 6 & 7 \\
\hline
\end{tabular}

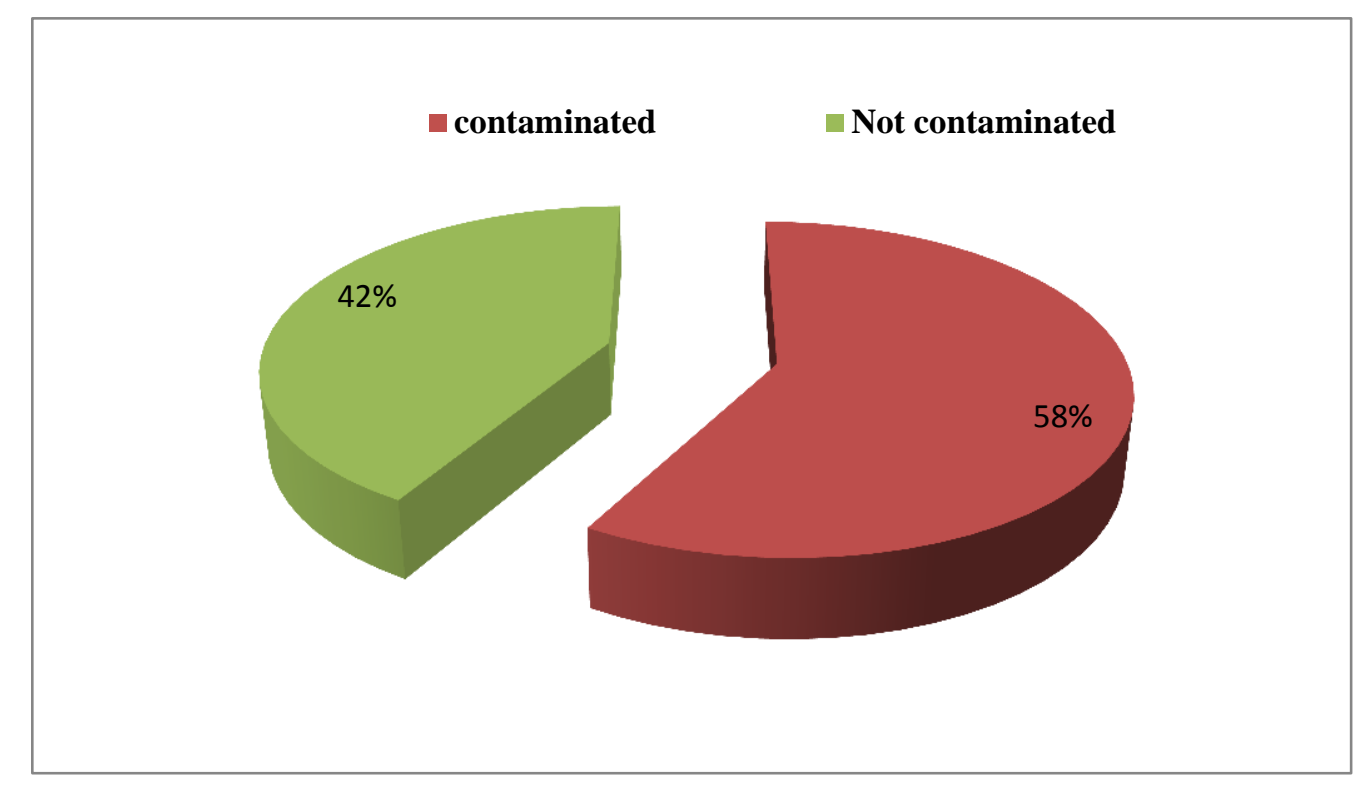

Fig.1 Contamination in Ground Water Resources of Urban Areas of Ujjain 


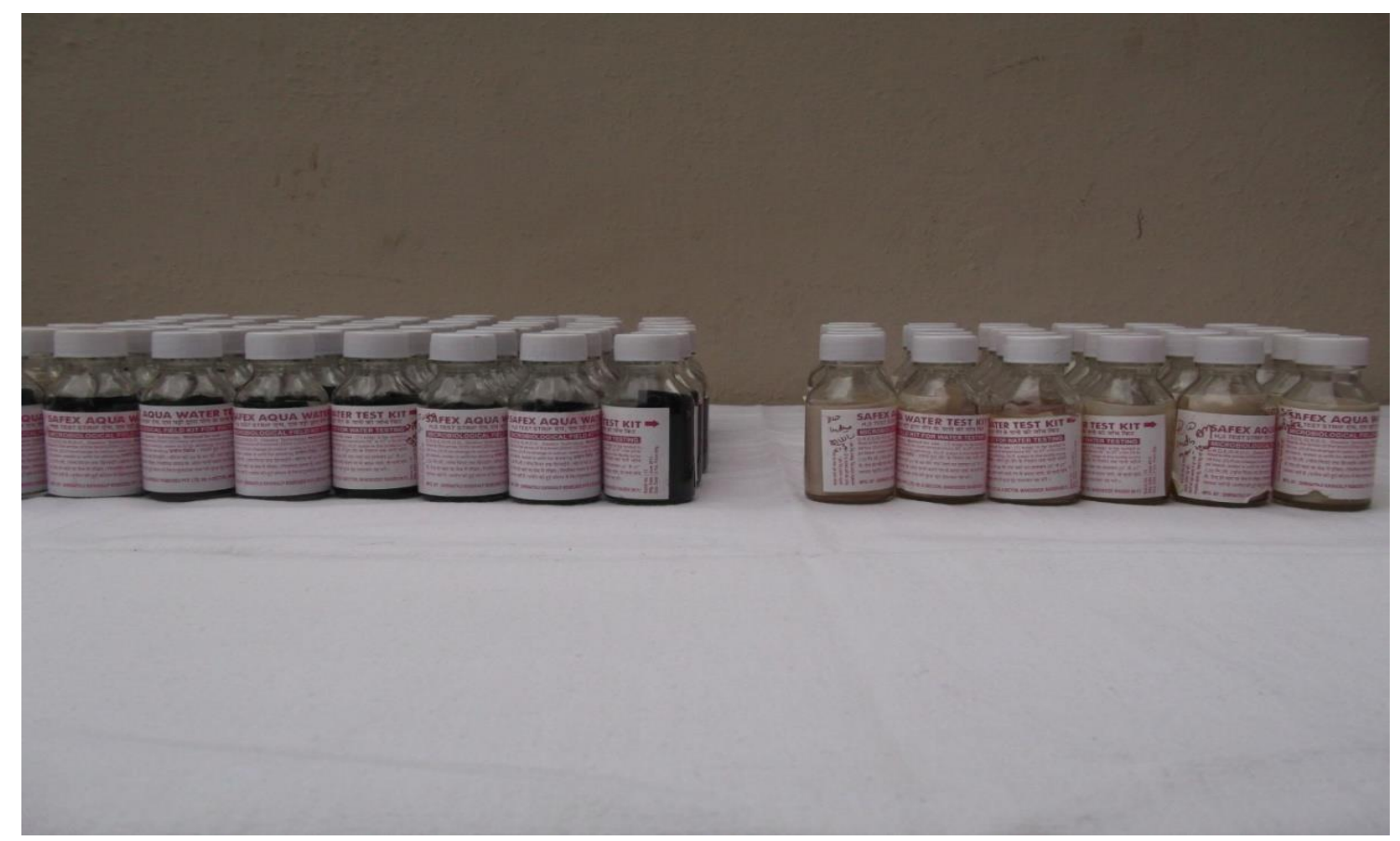

Fig. 2 Bacterial contamination of faecal origin in ground water samples of various Urban Areas of Ujjain ( $\mathrm{H}_{2} \mathrm{~S}$ strip test)

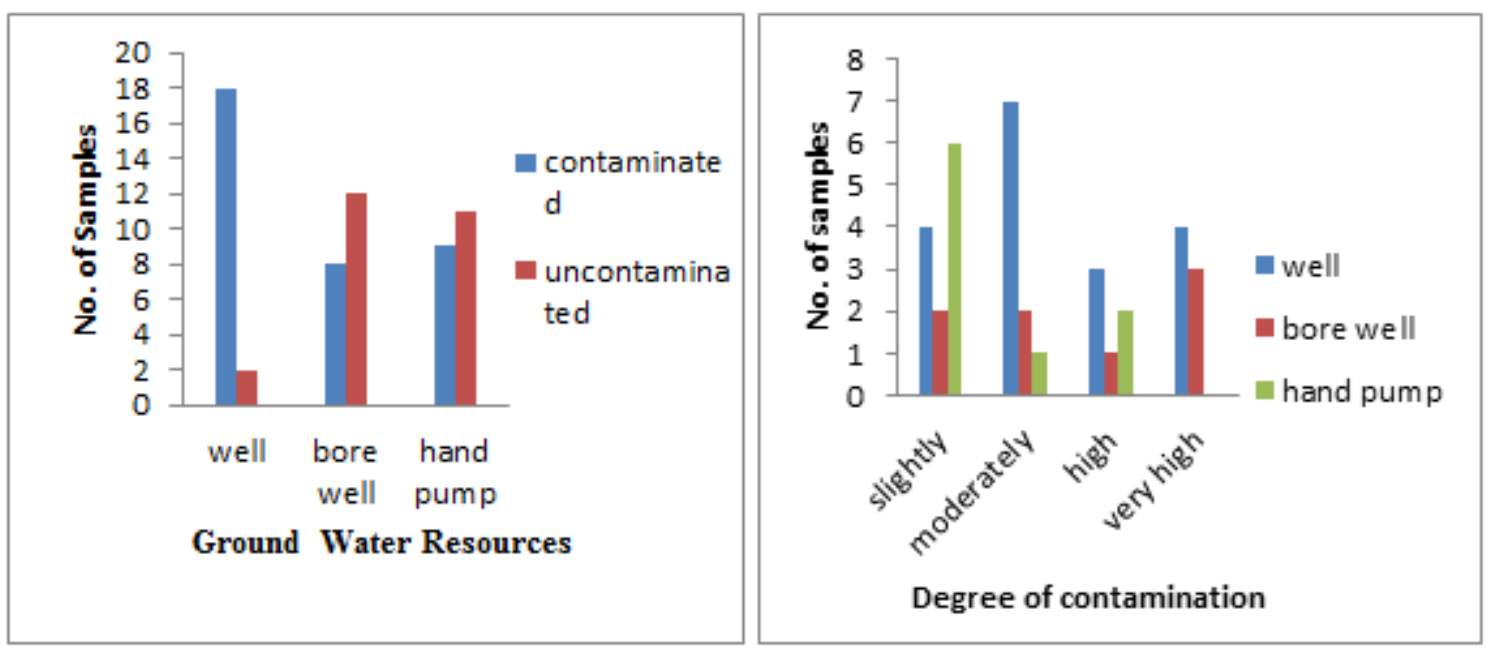

Fig.3 Faecal Contamination in Ground Water samples of Urban Areas of Ujjain ( $\mathrm{H}_{2} \mathrm{~S}$ Strip Test).

\section{References:}

[1.] Javed Ali, Naseem Ullah, Farhat Ali khan, Zia -ur- Rahaman, Israr ahmad, Said Hassan and Irshad ahmad(2013), Bacteriological quality analysis of drinking water of rural areas of Peshawar, Pakistan, American - Eurasian J.Agric.\& Enviorn. Sci.,13(9): 1202-1206.

[2.] Manja, K.S., Maurya, M.S. and Rao,K.M.(1982). A simple field test for the detection of faecal pollution in drinking water. Bulletin of the world health organisation, 60:797-801.

[3.] Onuigbo,A.C., Onyia,C.E.,Nwosu,I.G. and Oyeagu,U(2017). Impact of Bacterial pollution on hand - dug well water quality in Enugu, Enugu state, Nigria(2017), African journal of Enviornmental science and Technology, vol. 11(6), pp. 331-338.

[4.] Pahuja,S.(2010) Deep wells and Prudence towards pragmatic action for addressing ground water overexploitation in India. The world Bank, Washington, DC. The International Bank for Reconstruction \& Development the world bank report.

[5.] Sharma Neelam (2012), Ground water pollution at ujjain: An assessment of water quality at different localities ,Ph.D,Thesis, Vikram University,Ujjain.

[6.] Sowrabha , J and J.Narayana, Assessment of ground water quality using for drinking purpose in Shivamogga town, Karnataka, India, International journal of current microbiology and applied sciences (2014), vol. 3, No.12,pp. 381-388. 
[7.] Wyrwoll, P.(2012) Indian's ground water crisis. Global water forum. Gwf Discussion paper, 1228pp.

[8.] Yadav,krishna kumar(2012) Physico chemical analysis of selected ground water samples of Agra city,India. Recent Res. Sci. technol., 4(11); 51-54. 